Article

\title{
Factors Related with the Incidence of Severe Preeclampsia at the Hospital Dr M Djamil Padang
}

\author{
Nissa Prima Sari ${ }^{1}$, Bobby Indra Utama ${ }^{2}$, Meilinda Agus ${ }^{3}$ \\ ${ }^{I}$ Bachelor of Midwifery Program Faculty of Medicine Andalas University Jln. Niaga no. 56 Padang, Indonesia \\ ${ }^{2}$ Bachelor of Midwifery Program Faculty of Medicine Andalas University Jln. Niaga no. 56 Padang, Indonesia \\ ${ }^{3}$ Bachelor of Midwifery Program Faculty of Medicine Andalas University Jln. Niaga no. 56 Padang, Indonesia \\ SUBMISSION TRACK \\ A B $\quad \mathbf{S}$ T $\mathbf{R}$ A $\mathbf{C}$ T
}

Recieved: Oktober 29, 2017

Final Revision: Nopember 02, 2017

Available Online: Desember 15, 2017

\section{KEYWORDS}

Severe preeclampsia, risk factors, Hospital DR M. Djamil Padang

CORRESPONDENCE

E-mail: nissaprimasari@gmail.com
Preeclampsia is a condition characterized by an increase in maternal blood pressure of at least 140/90 mmHg accompanied by proteinuria and other symptoms that occur after 28 weeks gestation. The incidence of preeclampsia in hospital DR M Djamil Padang reached $33 \%$. The exact cause of preeclampsia remains unknown, but extreme maternal age, nulliparity, history of hypertension are suspected to be the risk factors for this. This study aims to determine the factors related with the incidence of severe preeclampsia in the hospital DR M. Djamil Padang.

This was observational analytic study with case control study design. The population is divided into two, the case population (all mothers with severe preeclampsia) and the control population (all mothers with no severe preeclampsia). The sample was 85 people taken by simple random sampling with the comparison between case: control (1:1). Data were taken from the patient's medical records. Data analysis was performed using univariate and bivariate using Chi square test with p value <0,05.

The results of this study showed there was a relationship between age $(p=0,001)$, parity $(p=0,020)$ and history of hypertension $(p=0,003)$ with the incidence of severe preeclampsia in the hospital DR M Djamil Padang. While the factor that has no significant relation is multiple pregnancy.

Mothers with age $<20$ years old or $\geq 35$ years old, nulliparity, and having a history of hypertension are more at risk for severe preeclampsia. Therefore it is expected for health workers especially midwives to increase awareness to patients especially for those who at risk of preeclampsia. 


\section{I.INTRODUCTION}

Health is one of the most crucial indicators in the development of a country. Therefore, the government is committed to improving health through the program "Indonesia Sehat 2025"

The goal of health development towards "Indonesia Sehat 2025" is to increase awareness, willingness, and healthy life for every person through the creation of a behavioral and healthy society, reaching quality health services fairly and equally, and have the highest health level in all areas Republic of Indonesia (Indonesia's Department of Health, 2009).

One of the indicators used in achieving this goal is to reduce maternal mortality from 262 per 100,000 live births in 2005 to 74 per 100,000 live births in 2025. But in reality the maternal mortality rate in Indonesia is still far from the target. Based on the report of Indonesia Health Demographic Survey (SDKI), the trend of maternal mortality rate from year to year has decreased significantly until 2010. The maternal mortality rate was 307 per live birth in 2002 then decreased to 228 per live birth in 2007 then decreased again to 125 per live birth in 2010. However there was a significant increase in 2012 that was 359 per live birth (SDKI, 2012). And by 2015 the maternal mortality rate dropped into 305 per live birth (Indonesia's Ministry of Health 2015)

To achieve the target of "Indonesia Sehat 2025" is certainly required a good commitment from government and society, considering that maternal mortality is still a major problem in Indonesia.According to WHO in 2016, the cause of maternal death is pre-existing condition (28\%), bleeding (27\%), hypertension in pregnancy (14\%), infection (11\%), complications of abortion $(8 \%)$, prolonged labour and others $(9 \%)$ and blood clots or embolism (3\%).

From the data it is seen that besides bleeding, it turns out that preeclampsia also occupies the highest percentage of maternal deaths. An estimated about 50,000 women worldwide died from preeeklampsia, the number of incidents varies by country, in Israel the incidence of preeclampsia by $2.8 \%$, in Scotland by $5.8 \%$ and $14.1 \%$ in Australia (Shamsi et al, 2013). According to Indonesia Health Demographic Survey in 2002-2003, the percentage of pregnant women had preeclampsia in Indonesia was 0.4 percent and mothers with eclampsia were 1.4 percent. In West Sumatra in 2011 the number of maternal mortality caused by eclampsia was 23 percent, in 2012 it decreased to 22.9 percent and in 2013 increased to 26.2 percent (Hanum, 2013). Meanwhile, according to the Annual Report of Padang City Health Office 2015 preeclampsia and eclampsia still remain the main cause of maternal death as much as 23.5 percent.

Preeclampsia is a condition in which the onset of hypertensive symptoms in pregnancy is accompanied by proteinuria. In severe preeclampsia can lead to eclampsia with symptoms of seizures. According to Djannah (2010) the incidence of preeclampsia in developing countries is about 0.3 percent to 0.7 percent, whereas in developed countries the incidence of preeclampsia is smaller which is 0.05 percent to 0.1 percent.

The exact cause of preeclampsia is still unknown, many theories put forward as the cause of preeclampsia, but with many theories can not be explained all the things related to this disease (Wiknjosastro, 2010). Apparently preeclampsia is not associated with a single factor, but many factors. The factors that are often found as risk factors for preeclampsia are aged under 20 years and over 35 years, obesity, multiple pregnancy, history of preeclampsia descent, economic status, etc. However, among the factors found it is often difficult to determine which is the cause and which is the result (Manuaba, 2012). 
Hospital DR M. Djamil Padang is a government hospital located in Padang City. Besides as an educational hospital, Hospital DR M. Djamil is also a referral hospital that receives many cases, including obstetric cases. Report Data the authors got from the medical record hospital DR M. Djamil, the number of severe preeclampsia cases in 2014 was 20.14 percent and in 2015 increased to 32.5 percent and the latest data in 2016 incidence of severe preeclampsia was 33 percent.

Based on preliminary observations in the medical record of hospital DR $\mathrm{M}$. Djamil, among the risk factors associated with severe preeclampsia, the authors only chose risk factors such as age, parity, history of hypertension, and multiple pregnancy due to limitations of author and medical record of hospital DR M. Djamil Padang. Based on that, the authors were interested to know Factors Associated with the Insidence of Severe Preeclampsia at Hospital Dr M. Djamil Padang
November 2016 - December 2017. The sample size was 170 people taken by Simple random sampling with comparison between case : control (1: 1). Data were taken from the patient's medical records. The data analysis used is Chi square.

\section{RESULT AND DISCUSSION}

The subject of this study was 170 respondents. Data collected from patient's medical record from January to August 2017.

\section{Limitations of study}

This study is inseparable from various limitations and inevitable biases such as :

1. This study used secondary data obtained from the patient's medical records, so the validity of data in this study depends on the validity of data in the medical record.

2. Not all variables that may be the risk factors for severe preeclampsia can be taken for this study, as they should be

Table 1 : Frequency Distribution Case and Control at Hospital DR M. Djamil Padang

\begin{tabular}{cccc}
\hline Variable & Population & Subjects & Percentage \\
\hline Case (preeklampsia) & 223 & 85 & $38,49 \%$ \\
\hline $\begin{array}{c}\text { Control } \\
\text { (non preeklampsia) }\end{array}$ & 1051 & 85 & $8,08 \%$ \\
\hline
\end{tabular}

\section{METHODS}

This was observational analytic study with case control design. The population is divided into two, the case population (all mothers with severe preeclampsia) and control populations (all mothers with no severe preeclampsia). The location chosen for this study is hospital RSUP DR M. Djamil Padang. The study was conducted in based on availability for some data in the medical record format.

Table 1 showed the frequency distribution of subjects used in this study. Case group were mothers with severe preeclampsia which was 85 cases from 223 cases from January to August 2017 or $38.49 \%$. While the control group was all mothers with other complications (non preeclampsia) which were also 85 cases from a total of 1051 non preeclamptic women $8.08 \%$. 
Table 2 : Frequency Distribution of Factors Related with the Incidence of Severe Preeclampsiaat Hospital DR M. Djamil Padang

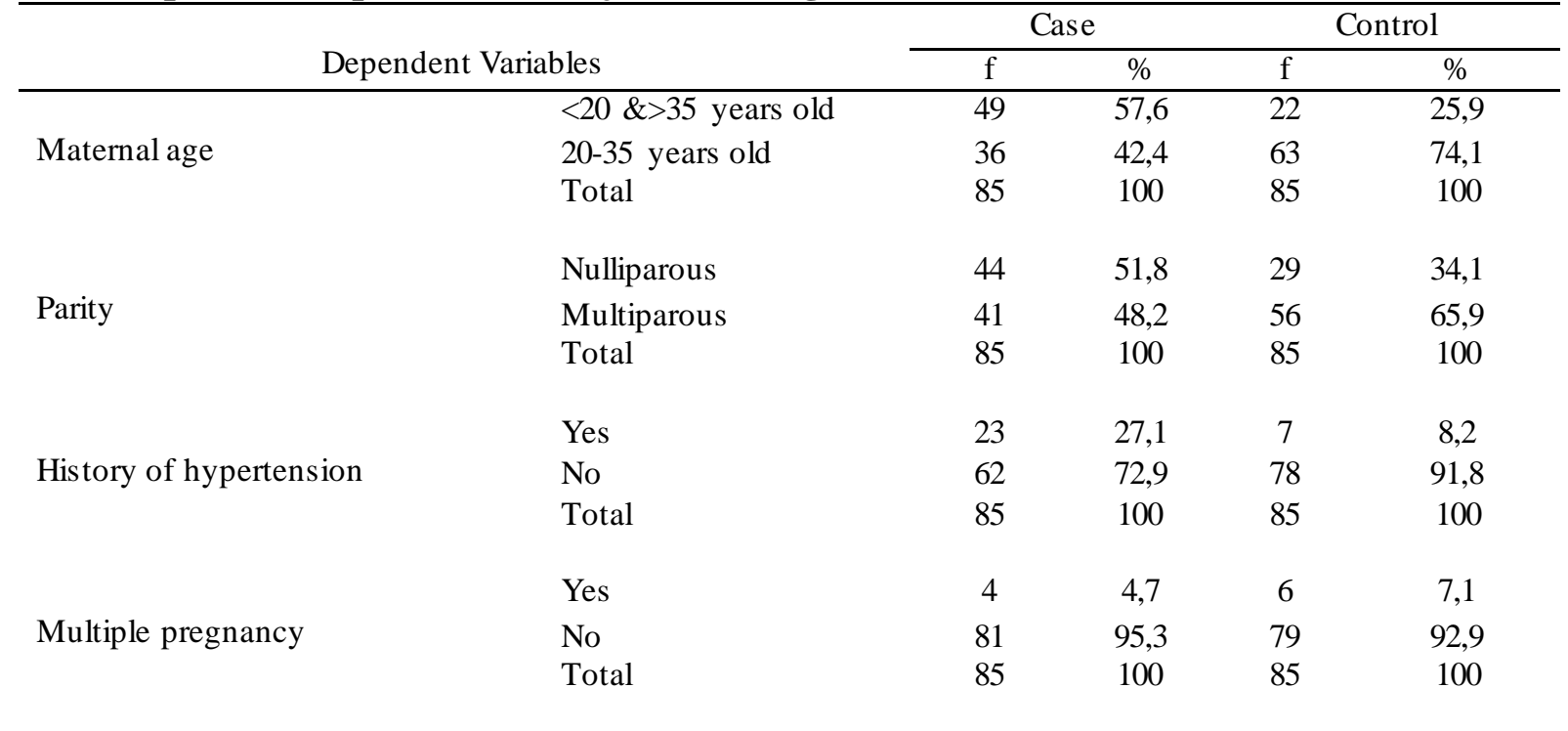

Table 2 showed a detailed frequency distribution of factors associated with severe preeclampsia, showing that more maternal risky age to be found in severe preeclampsia group $(57,6 \%)$ similarly to nulliparity dominantly found in the preeclampsia group $(51,8 \%)$ while mothers with a history of hypertension accounted for $27.1 \%$ in preeclampsia group and multiple pregnancies was $4.7 \%$ in those with severe preeclampsia group.

Based on table 3 the persentage respondents who had maternal risky age for severe preeclampsia $(57,6 \%)$ is greater compare to respondents who didn't had severe preeclampsia $(25,9 \%)$.

Statistical analysis showed there was a significant association between maternal age with severe preeclampsia incidence $(p=$ $0,000)$. From the analysis we knew that risky maternal age was 3,989 times more likely to develop preeclampsia compare to unrisky maternal age.

This is agreed with a study by Nursal (2015) at Hospital M. Djamil which also found most of respondents were at risky age which was 55,9\% in case group and 20,6\% in control group and $\mathrm{p}$ value 0,006 and $\mathrm{OR}=8,3$ which means mother with risky age 8,3 times more likely to develop severe preeclampsia compare to non risky mother.
Another study by Langelo (2013) showed maternal's age $>20$ and $\geq 35$ were 3.37 times more likely develop preeclampsia with $p$ value 0,000 which statistically means there was a significant relationship between maternal age with severe preeclampsia incidence.

But different findings found by Kashanian study in 2011 which showed that risky maternal age has no relationship with severe preeclampsia with $p$ value 0,75 and OR $=0,9$ which means mothers with advanced age $>31$ years old is 0,9 times more likely to develop severe preeclampsia compare to younger mother $(<31$ years old).

This is agreed based on theory in Cunningham et al (2014) which stated that maternal age $<20$ or $>35$ years old is more at risk for complication during pregnancy which bad for both mother and fetus. Maternal age <20 years old, the uterine size is not normal yet, so the likelihood of complication in pregnancy become greater. While maternal age $>35$ years old there is degeneration process which leads to structural and functional changes in peripheral blood vessels which responsible for increased of blood pressure and making it more likely to experience preeclampsia 
Based on the results of this study that risky maternal age is more likely to develop preeclampsia. Maternal age $<20$ years and $>$ 35 years will affect maternal health in pregnancy and childbirth. It is therefore very important for mothers to know a safe age for pregnancy and to know various risks of pregnancy at such risky ages. Therefore, it is without preeclampsia (32.9\%).Statistical analysis showed a significant relationship between maternal parity with the incidence of severe preeclampsia $(\mathrm{p}=0,020)$. From that it is known that nulliparous mother has a probability of 2,185 times to experience severe preeclampsia compared with multiparous mother

Tabel 3 : Factors Related with the Incidence of Severe Preeclampsia at Hospital DR M. Djamil Padang

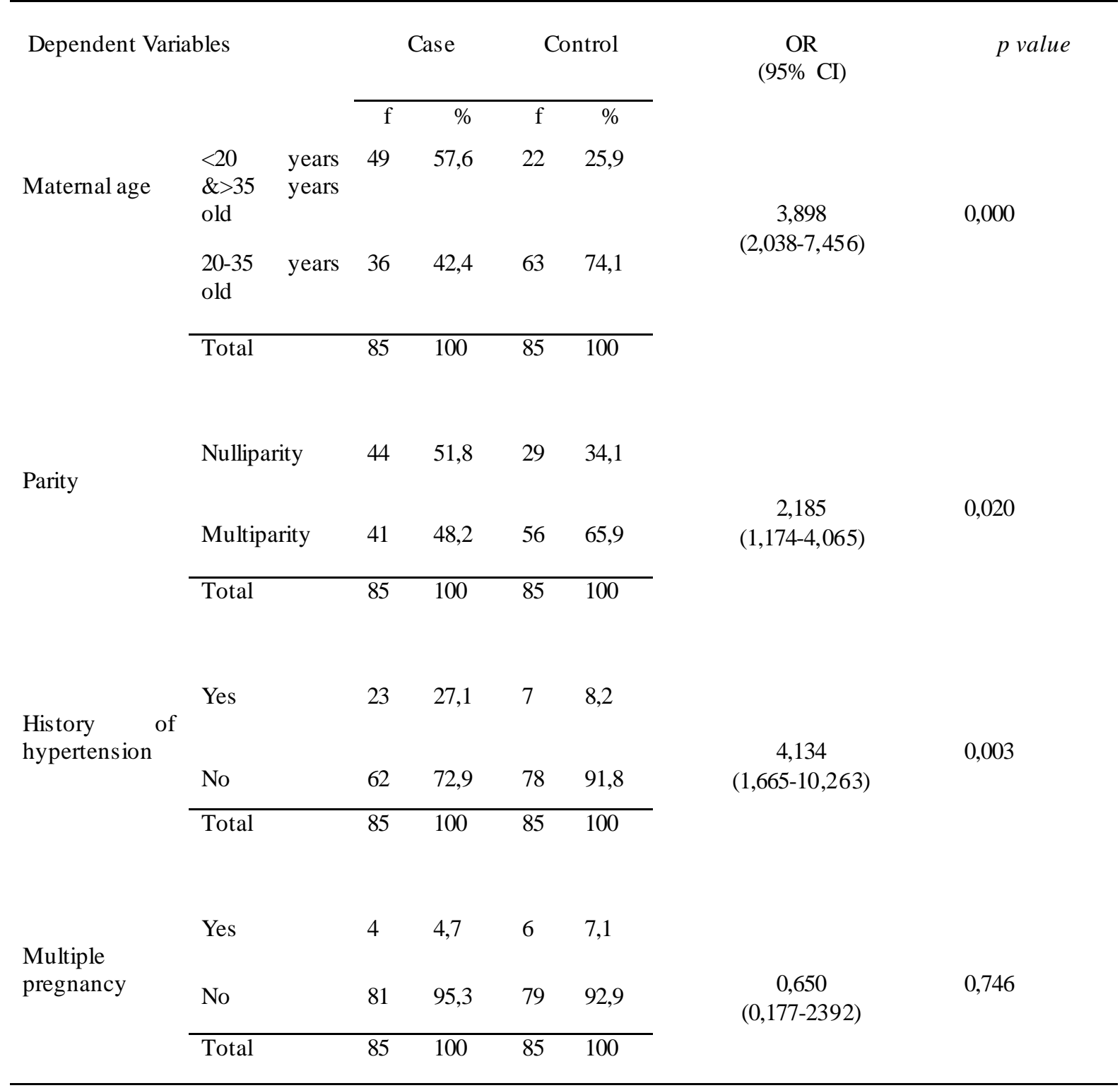

important to prepare for a safe age during pregnancy to avoid maternal complications including preeclampsia

Table 3 also showed that the percentage of respondents in the nulliparous mother group who experienced severe preeclampsia $(51.8 \%)$ was higher than those
This finding is in agreement with the finding of others. Astrina's study (2015) in Panembahan Bantul Hospital concluded that there was a significant relationship between nulliparity with the incidence of preeclampsia with $\mathrm{OR}=2,999$ which means the probability of nulliparous mother is 2,999 
times to develop preeclampsia compared with multiparous mother. Study by Indriani (2011) which revealed nulliparous mothers is 1.222 times more likely to develop preeclampsia and Afridasari study (2013) which concluded there was a significant relationship between the status of gravida with the incidence of ssevere preeclampsia with $\mathrm{OR}=2,881$ which means nulliparous mother were 2,881 times to develop preeclampsia than multiparous mother. But these findings is contrary to Nursal study (2014) which concluded that multiparous mothers are more at risk for preeclampsia than nullipara mothers

Young and nulliparous women are particularly vulnerable to experience preeclampsia, and the incidence of preeclamptic women between 3 to 10 percent. different from multiparous women with fewer incident percentages. (Cunningham, 2014). In theory, nulliparous woman is more at risk to develop preeclampsia than multiparous woman because preeclampsia usually occurs in women who are first time exposed to chorionic villi. This occurs because in those women the immunologic mechanisms of blocking antibody formation performed by HLA-G (human leukocyte antigen G) to placental antigen have not been fully formed, so the process of trophoblast implantation into the mother's desidual tissue becomes disturbed. Nulliparous woman is also vulnerable to stress during labor which will stimulate her body to produce cortisol. The effect of cortisol is to improve the sympathetic response, so that cardiac output and blood pressure will also increase (Irianti, 2013).

Therefore, both multiparous and nulliparous woman should have counseling for contraception to a professional health worker in order to control the number of births, as to prevent and avoid the risk of preeclampsia.Based on table 3 it can be seen that the percentage of respondents who had history of hypertension who experienced severe preeclampsia (27.1\%) more than respondents who did not experience severe preeclampsia $(8.2 \%)$.

The Result of statistical analysis showed a significant relationship between history of maternal hypertension with severe preeclampsia incidence $(\mathrm{p}=0,003)$. From the analysis it is seen that mothers with a history of hypertension had a likelihood 4.134 times to develop severe preeclampsia compared with mothers with no history of hypertension before.

This study is in agreement with Radjamuda study (2014) which concluded that women with prior hypertension history were at risk for preeclampsia with $\mathrm{p}$ value 0.02 which means there was a significant relationship between history of hypertension with severe preeclampsia. Similarly, the results of Moghadam study conducted in Iran in 2012 revealed that there was a significant relationship between mothers with a history of chronic hypertension with the incidence of severe preeclampsia and $\mathrm{p}$ value 0.001 and $\mathrm{OR}=3.17$ which means women with a history of hypertension 3.17 times to develop severe preeclampsia compared with normotension women.

Hypertension is a disorder of the blood vessels that result interference in oxygen supply and nutrients carried by the blood obstructed to the body tissues that need it. In general, hypertension is an asymptomatic state, where high blood pressure in the arteries can leads to increased risk for cardiovascular-related diseases such as stroke, renal failure, heart attack, and kidney damage (Widyaningrum, 2012).

A history of chronic hypertension, previous hypertensive vascular disease or essential hypertension is risk factors for the incidence of preeclampsia (Poston et al., 2006). Thus, the likelihood of having preeclampsia will increase in women with a history of chronic hypertension, because the placental blood vessels have been impaired. Therefore, mothers with a history of hypertension should be alert as early as possible for preeclampsia with optimal antenatal care.From table 3 it can be seen that the percentage of respondents in the 
multiple pregnancy group who experienced severe preeclampsia $(4.7 \%)$ was less than those who did not have severe preeclampsia $(7.1 \%)$.

The results of statistical analysis showed there was no significant relationship between multiple pregnancy with severe preeclampsia $(\mathrm{p}=0,744)$. With $\mathrm{OR}=0.650$ or OR value $<1$ which means OR protective risk is caused because the percentage of multiple pregnancy is less in case group than control group.

This is in agreement with Andriani's study in 2009 revealed that there was no significant relationship between multiple pregnancies and the incidence of preeclampsia with $\mathrm{OR}=1,460$ and Hanum's study in 2013 concluding that there was no significant association between multiple pregnancies and severe preeclampsia. However, the results of this study differed from a multicentre study by Sibai in 2000 revealed that women with multiple pregnancies were more likely to have gestational hypertension and preeclampsia. This is not in agreement with the theory that preeclampsia is more common in multiple pregnancies, this is because the increase of placental mass in multiple pregnancies can lead to an increase in circulating levels of tyrosine kinase-1, which is antiangiogenic circulating in the origin of the placenta, and may play an important role in the pathophysiology preeclampsia. (Magee, Dadeelszeen et al, 2016)

In this study there was no relationship between multiple pregnancies and severe preeclampsia. This may be due to the small frequency distribution of multiple pregnancy in both groups and may also be due to the frequency distribution of multiple pregnancy mothers who did not develop preeclampsia is more than frequency distribution of multiple pregnancy mothers with preeclampsia.

\section{CONCLUSION}

Risky maternal age <20 years and > 35 years, nulliparity, and history of hypertension were found to be associated with severe preeclampsia incidence in this study. Therefore it suggested for health workers, especially midwives to increase the frequency of counseling either personal or group regarding the impact and prevention of preeclampsia for mothers and early detection for all pregnant women to avoid maternal complications such as preeclampsia and can refer them as soon as possible 


\section{REFERENCES}

Afridasari dkk. Analisis Faktor Resiko Kejadian Preeklampsia Kendari: Universitas Haluoleo; 2013

Andriani, F. 2009. "Faktor-faktor yang berhubungan dengan Preeklampsia di RSU Dr. Sutomo Surabaya". Skripsi. Sarjana Universitas Airlangga

Angsar, M. D. 2013. Hipertensi Dalam Kehamilan dalam Ilmu Kebidanan Sarwono Prawirohardjo. Edisi 4. PT Bina Pustaka. Jakarta

Astrina, N. 2015. Analisis Faktor yang Berhubungan dengan Preeklampsia/Eklampsia di RSUD Panembahan Senopati Bantul. Skripsi. Diploma Bidan pendidik STIKES Aisyiyah Yogyakarta

BPS. 2003. Survey Demografi dan Kesehatan Indonesia (SDKI) 2002-2003. Jakarta: BPS

Briley, A. 2013. The Midwife's Labour and Birth handbook. 2 ${ }^{\text {nd }}$ Ed. Blackwell Publishing. Terjemahan H. Y Kuncara. 2013. Persalinan dan Kelahiran. Edisi 2. EGC. Jakarta

Castro, L.C. 2010. Hypertensive Disorders of Pregnancy Dalam Essentials of Obstetrics and Gynecology. Editor : Hacker dan Moore'. Edisi 5. Saunders Elsevier. Philadelphia

Cruickshank, M. Shetty, A. 2009. Obstetric and Gynecology Clinical Cases Uncovered. WileyBlackwell. UK

Cunninghan F, Gary, dkk. 2014. Edisi 24. Obstetri Williams. Jakarta : EGC

Data Rekam Medis Rumah Sakit Umum Pusat DR M. Djamil Padang. 2015 dan 2016.

Indonesia's Department of Health, 2009. Sistem Kesehatan Nasional. Jakarta.

Dinas Kesehatan Kota Padang. Profil Kesehatan Kota Padang 2013. Padang: Dinas Kesehatan Kota Padang; 2014

Dinkes Provinsi Sumatera Barat. Laporan Tahunan Dinkes Provinsi Sumatera Barat. Padang: Dinkes Provinsi Sumatera Barat; 2014.

Djannah, Sitti nur dan Ika Sukma Arianti. 2010. Gambaran Epidemiologi Kejadian Preeklampsia/Eklampsia di RSU PKU Muhammadiyah Yogyakarta Tahun 2001-2009. Jurnal. Buletin Penelitian Sistem Kesehatan

England, L, Zhang, J. 2007. Smoking and Risk of Preeclampsia: A Systematic Review. Division of Reproductive Health, Centers for Disease Control and Prevention, Department of Health and Human Services, Atlanta, GA, 2 Division of Epidemiology, Statistics, and Prevention Research, National Institute of Child Health and Human Development, Department of Health and Human Services, Bethesda, MD

English, F.A. Kenny, L.C. McCarthy, F.P. 2015. Risk Factors and Effective Management of Preeclampsia. Integrated Blood Pressure Control. 2015(8) : 7-12

Eugene, W. Waite, K. Bennet, M. 2010. Retinal Manifestation of Preeclampsia. http://retinatoday.com/pdfs/0910RT_Pearls.pdf 4 April (12:25)

Hanum, H. Faridah. Faktor Resiko yang Berhubungan dengan Kejadian Preeklampsia di RSUP M. Djamil Padang Tahun 2013 (Jurnal) Padang ; Poltekkes Kemenkes Padang ; 2013

Indriani N. Analisis Faktor-faktor Yang Berhubungan Dengan Kejadian Preeklampsia Pada Ibu Bersalin Di RSUD Kardinah Kota Tegal Tahun 2011. Jakarta: Universitas Indonesia; 2012

Institute of Obstetrians and Gynecologist, Royale Collage of Physicians of Ireland. 2013. The Diagnosis and Management of Preeclampsia and Eclampsia. Clinical Strategy and Program Directorate. Ireland

Itoh H, Kanayama N. 2014. Obesity and Risk of Preeclampsia. Med J Obstet Gynecol 2(2): 1024

Kashanian, M. Baradaran, H.R. Bahasadri, S. Alimohammadi, R. 2011. Risk Factors for Preeclampsia: A Study in Tehran, Iran. Tehran University of Science 6 (14). November $2011: 412-415$ 
Indonesia's Ministry of Health 2015. Profil Kesehatan Indonesia 2015. Jakarta : Kemenkes RI ; 2016

Langelo, Wahyuni,dkk. 2013. Faktor resiko Kejadian Preeklampsia di RSKD Ibu dan Anak Siti Fatimah Makasar Tahun 2011-2012. Jurnal. Fakultas Kesehatan Masyarakat Universitas Hassanudin

Lazarov, S. Lazarov L, Lazarov, N. 2016. Complications of Multiple Pregnancies. Trakia ournal of Science 14 (1) : 108

Lloyd, C. 2014. Myles Textbook for Midwives. $16^{\text {th }}$ Ed. Elsevier Science Limited. UK. Editor : Marshall, J, Raynor M

Lusiana, N. 2014. Faktor-faktor yang Berhubungan dengan Kejadian Preeklampsia pasa Ibu Bersalin di Ruang Camar II RSUD Arifin Achmad Provinsi Riau Tahun 2014. Jurnal Kesehatan Komunitas

Magdalena, M. Historyati, D. 2013. Gambaran Faktor Penyebab Preeklampsia pada Kehamilan di Wilayah Kerja Puskesmas Tembelang Jombang. D3 Kebidanan. Stikes Pemkab Jombang

Magee, LA. Dadeelszen, PV. Stones, W. Mathai, M. 2016. The FIGO Textbook of Pregnancy Hypertension : An evidence-based guide to monitoring, prevention and management. The Global Library of Woman's Medicine. London

Maternal mortality: World Health Organization (WHO), 2014.

Mose, J.C. Irianti, S. 2013. Hipertensi dalam Kehamilan. Obstetri Patologi. EGC : Jakarta

Moghadam, AD, Koshravi, A. Sayehmiri. 2015. Predictive Factors for Preeclampsia in Pregnant Woman : A Unvariate and Multivariate Logistic Regression Analytic. Biochimio Polonica.(4) 673-677

Nagayama, S. Ohkuchi, A. Usui, R. Matsubara, S. Suzuki, M. 2014. The Role of Father in the Occurance of Preeclampsia. Medical Journal of Obstetric and Gynecology. 2 (2) : 1029

Norwitz, E. 2008. At a Glance Obstetri and Ginekologi edisi 2. Jakarta : EMS

Notoatmodjo,S. 2010. Metodologi Penelitian Kesehatan. Rineka Cipta. Jakarta

Nursal D, Tameela P. Fitrayeni. 2015. Faktor Resiko Kejadian Preeklampsia di RSUP M. Djamil Tahun 2014. Jurnal Kesehatan Masyarakat Andalas. Program Studi Kesehatan Masyarakat Fakultas Kesehatan Masyarakat Universitas Andalas

Opitasari, C. Andayasari, L. 2014. Parity, Education Level and Risk for Preeclampsia in Selected Hospital in Jakarta.Health Science Indones 2014(1) : 35-9

Puspitasari, A. 2009. Faktor-faktor yang berhubungan dengan kejadian preeklampsia pada ibu hamil di RSUP Dr Kariadi Semarang. Fakultas Ilmu Kesehatan Masyarakat. Universitas Negeri Semarang

Poston, L. Briley, A.L. Seed, P.T. Shennan, A.H. 2006. Vitamin C and E in women at risk f Preeclampsia (VIP Trial) : randomised placebo-controlled trial. Lancet

Prawirohardjo, S. 2011. Ilmu Kandungan : Jakarta. PT Bina Pustaka Sarwono Prawirohardjo

Radjamuda, N. Montololu, A.2014. Faktor Resiko yang Berhubungan dengan Hipertensi pada Ibu Hamil di Poli Klinik Obs-Gin Rumah Sakit Jiwa Prof. Dr. V.L Ratumbuysang Kota Manado. Jurnal. Jurusan Kebidanan STIKES Muhammadiyah Manado

Rozikhan. 2007. Faktor-faktor resiko terjadinya preeklampsia berat di rumah sakit Dr. $H$ Soewondo Kendal. Tesis. Magister Epidemiologi. Universitas Diponegoro

Saifuddin, Abdul Bari. 2013. Buku Panduan Praktis Pelayanan Kesehatan Maternal dan Neonatal. Jakarta : Yayasan Bina Pustaka Sarwono Prawirohardjo

Saxena, R. 2010. Bedside Obstetric \& Gynecology. $1^{\text {st }}$ Edition. Jaypee Brothers Medical Publisher

Sepidarkish, M. Hashiani, A. Maroufizadeh, S. Vesali, S. Pirjani, R. Samani, R. 2016. Association Between Previous Spontaneous Abortion andPreeclamsia During a Subsequent Pregnancy: Wiley. Obsteric Gynecology 
Sibai B.M., Hauth J., Caritis S. (2000) Hypertensive disorders in twin versus singleton gestations. Am. J. Obstet. Gynecol. 182:938-42.

SDKI.2012. Survey Demografi dan Kesehatan Indonesia 2012. Badan Kependudukan dan Kelarga Berencana Nasional Kementrian Kesehatan

Shamsi, U. Saleem, S. Nishteer, N. 2013. Epidemiology and Risk Factors of Preeclampsia ; An Overview of Observational Studies. US National Library of Medicine Enlisted Journal $6(4): 292-300$

Sukaesih, S. 2012. Faktor - Faktor yang Berhubungan dengan Pengetahuan Ibu Hamil Mengenai Tanda Bahaya dalam Kehamilan di Puskesmas Tegal Selatan Kota Tegal Tahun 2012. Skripsi. Program Sarjana Kesehatan Masyarakat Universitas Indonesia

Varney, H. 2010. Buku Ajar Asuhan Kebidanan. Edisi 4. Jakarta. EGC

Widyaningrum, S. 2013. Hubungan Antara Konsumsi Makanan dengan Kejadian Hipertensi pada Lansia. Skripsi. Fakultas Kesehatan Masyarakat Universitas Jember

Wiknjosastro, G. dkk. 2010. Ilmu Kebidanan. Yayasan Bina Pustaka Sarwono Prawirohardjo. Jakarta

Zahrani, A. 2016. Faktor-faktor yang berhubungan dengan kejadian Preeklampsia pada ibu hamil di Kota Semarang Tahun2015.Skripsi. Program D-IV Kebidanan STIKES Ngudi Waluyo 